\title{
An Identification of Unsuccessful, Failure Factors of Technology Innovation and Development in SMEs: A Case Study of Components and Material Industry
}

\author{
Sung-Wook Kang ${ }^{1}$ \\ ${ }^{1}$ Griffith Business School, Griffith University, Australia \\ Correspondence: Sung-Wook Kang, Department of International Business and Asian Studies, Griffith University \\ Australia, ON., Parkland Drive Southport Qld, Australia. Tel: 61-7-5552-9211. E-mail: \\ michael.kang@griffithun-i.edu.au
}

Received: June 7, 2012 Accepted: August, 30, 2012 Online Published: October 1, 2012

doi:10.5539/ijbm.v7n19p16 URL: http://dx.doi.org/10.5539/ijbm.v7n19p16

\begin{abstract}
Despite the widespread recognition of the important roles that innovative, technology-oriented small and medium sized enterprises (SMEs) play in most economies, relatively little research has been focused on the integrated aspects of technology, management and the related factors in the context of SMEs. Since there are no well-defined or established research models or frameworks, we adopted an exploratory, longitudinal approach to investigate key factors that affect success or failure business cases in Korean components and materials industry. With forty-five case study analysis, we found three important factors for technology-oriented SMEs business successes or failures. These include technology factors (market-oriented technology; timely innovative technology; technology innovation capability; patents), management factors (financial resource; management commitments; human resource; R\&D capability; commercialization capability), and the related factors (top managers' ethical issues; transparency in R\&D budgets; lack of commitments for success). We highlight the importance of the integrative approach which combines technology, management, and the related factors to examine successful or failing business cases. Further studies will benefit from our findings to develop theoretical models and examine other industries.
\end{abstract}

Keywords: innovation, market-orientation, components and materials industry, technology innovation capability, management capability

\section{Introduction}

Encouraging of innovation in small and medium-sized enterprises (SMEs) has been at the centre of governmental policy incentives owing to the important role in economic development. Despite their important role, there has been little attention on innovation in SMEs. Rather majority of researches have focused on innovation in large-sized enterprises (Forsman, 2011). More importantly, understanding of why SMEs fail and succeed is crucial for business sustainability by identifying factors to business success and failure. Previous studies suggested that success factors vary in different countries (Benzing et al., 2009), but failure factors are little known in SMEs.

Since 1990, the Republic of Korea introduced policy incentives to SMEs for technology-oriented innovation. In particular, the components and material industry received a particular attention from the Korean government due to the importance of the strategic roles in the economy. The emerging competitive components and materials industry has been instrumental in leading and influencing industry-wide competitiveness, manufacturing growth and exports. An important requirement to develop core parts and materials is original technology. This in turn cultivates and enables global supply companies to further innovate technology. The Korean Government (Ministry of Knowledge and Economic) understood this need and have designed effective policies in order to create opportunities for companies to achieve their innovative technological objectives. The program, the components and materials development project (CMDP) is one of the most successful national research and development (R\&D) programs has been in operation for 12 years since 1990.

But in spite of the excellent performance of the CMDP, some SMEs do fail each year. The primary reason for their failure can be attributed to a lack of funds for R\&D due to decreased profitability and growth, and also to the loss 
of key human resources, wherein these factors impact companies' success in achieving technological innovation. But so far, little research relating to the systemic cessation/failure of technology innovation and success can be sourced (Choi, 2010; Lussier \& Halabi, 2010).

The purpose of this study is to discover factors and practices that affect SMEs' business failure in the Korean components and material industry wherein companies have received government funds to develop innovative technology. The structure of this paper is as follows. The following section introduced a theoretical background and literature review. The subsequent methodology section provides the details of methods and data collection. The fourth section presents the findings of the analysis. The results are discussed. The final section provides conclusions of the study and the implications for future research.

\section{Literature Review}

Compared to large companies, SMEs have unique advantages; they are quicker to respond to the needs of consumers and can increase their growth rapidly through the sale of small innovative products. SMEs associate successful R\&D with innovative activity. Capabilities in $R \& D$ relate to companies systemic activities whereby they use the knowledge they already have to innovate or to utilize knowledge promoted by an internal independent agency or external agency (Brockman \& Morgan, 2003). In general, capabilities refer to the capacity to deploy or exploit the resources of an organization, so the capabilities have an impact on innovation capacity. According to Szeto (2000), innovation capacity can be described as "a continuous improvement of capabilities and resources that an enterprise possess in order to explore and exploit opportunities for developing new products to meet customer market needs. Innovation capacity of SMEs has often been regarded as the formal R\&D activities or companies and new products development (Kirner et al., 2009). Ongoing R\&D activity increases the SMEs' competitiveness and it is also evaluated as a major factor of market survival and business success (Lee and Jeong, 2010).

Studies have increased steadily as the impact of R\&D capabilities grows with the success of business innovation. It has been empirically analyzed that the increase of $R \& D$ investment has a positive effect on sales revenue, profit, productivity and research, as well as on how R\&D capabilities influence new technology and new products are developed (Chan et al., 1990; Lee et al., 2001; Yam et al., 2004).

According to Kim (2005), technology innovation-oriented SMEs are expressed as innovative SMEs, technology intensive SMEs, and innovative SMEs depending on the research point of view. For example, Bank of England (2001) in the UK defines technology-based innovative SMEs as companies heavily dependent on scientific and technology-based products or as companies providing services which adopt new technology or existing technology in an innovative way, or as companies generating competitiveness significantly from technological activities.

In a similar vein, technological innovation could be described as organizational changes which are brought about by the application of newly developed technologies to facilities, systems, processes, programs, and services of the organization. In this regard, innovation can also be described as the commercialization of developed technology being considered as a major factor in terms of market orientation (Burgelman \& Maidique, 1995).

Park (2008) maintains that "commercialization of technology defined as various activities and processes that add value through technology transfer, trade, proliferation, application (p.117-118)." Also, the idea of commercialization of the technology should be carefully approached because it is easily influenced by various internal and external factors including product development, manufacturing and marketing.

As a determinant factor of technology commercialization, Kim (1991) and others present three important factors: technology, economy and corporate characteristics. To elaborate, technology factors include technology information capability, technology selection capability, absorption capability, organizing capability, learning capability, and R\&D capability. Management factors include market research capability, market condition, product characteristics, marketing capability, and financial management skills. Corporate characteristics include the company's experience, financial capability, technology innovation capability, and management capability.

In this study, capabilities of technology and management in SMEs are emphasized as a source of the company's competitiveness as business environment changes rapidly. As described above, technology competitiveness includes technology information capability, technology selection capability, absorption capability, organizing capability, learning capability, and R\&D capability which are classified as hardware aspects. Management competitiveness factors include market research capability, market condition, product characteristics, marketing capability, and financial management skills which are classified as software aspects. In order for SMEs to succeed with market-oriented technology innovation without missing opportunities, cooperation between technology and 
management abilities is essential (Teece, 1992; Souitaris, 2002). Eventually the literature concluded that the source of SMEs competitiveness is due to the company's ability to innovate technology and manage business operations in market competition.

Lee and Lee (2009) found that there is a characteristic difference between successful companies and unsuccessful companies regarding competitive strategy, networking strategy, resources, capabilities and the environment. Duk (2007) examined a venture company's risk management, and through his research he found that there is a difference between successful companies and unsuccessful companies regarding human, financial, social and technological resources, as well as strategy. Kyung and Lee (2010) claim that success determinants of SMEs include the Chief Executive Officer's (CEO) characteristics, company size, and the company's strategic commitment. Lee and Jung (2008) proved through their research on electronic companies that the sales growth rate, R\&D investment rate, technical staff, and external partners of a company have a positive influence and affect on technology innovation. Furthermore, Kim (2007) emphasized the importance of human resources development based on his research of innovative SMEs.

In particular, as the parts and materials of SMEs are set in the middle, between the upstream and downstream industry value chain, their cooperation and relationship with upstream and downstream members of the industry value chain seems to influence their innovation favourably in terms of technology information, demands for developed technology, and financially. No theory has been systematically developed as yet on the crucial factors that affect business failure (Lussier and Halabi, 2010), also there are no well-defined or established research models or frameworks. Therefore, in this research, we will adopt an exploratory case approach to investigate key factors that affect the success and failure of business cases in the Korean components and materials industry.

\section{Research Method}

As indicated above, as there is no systematic theoretical framework and research relating to success and failure factors of technology innovation, we will be adopting an exploratory case approach to propose our theoretical development. Yin (2003) emphasized that the case study research approach would be the most appropriate method if the scope and content of the research target is not fully developed and verified. In addition, Eisenhardt (1989) and Eisenhardt and Grabner (2007) assert that a case study research approach would be most appropriate where the research field has no established theoretical system.

Why SMEs are facing the R\&D failure during the innovation process has not been fully explored yet, we aim to fill the gap in theories of technology development and innovation process. Through literature review, we found that there is limited number of studies to identify factors for hindrance of successful R\&D and innovation process. More importantly, there is little empirical evidence to explain why some SMEs achieve relatively poor performance in R\&D and product innovation; as a result, they gain the failure label.

In this study, the case study approach is used to catch the complexity of a case when the case in itself is of special interest (Stake, 1995). As Yin (2003) argued, the case study approach enables an investigation to achieve the holistic and meaningful characteristics of real-life events; we employed the case study for undertaking in an exploratory study for this subject. Therefore, the method for this study will be used to explain 'why' and 'how' some SMEs face the cessation or failure.

This case study was conducted following the advice of Miles and Huberman (1994), through the phase of data reduction, data display and conclusion drawing. The collected data was processed and gradually condensed into tables. By focusing on failure/cessation factors, the qualitative data was transformed through selection and summarising into patterns.

In addition to case study based on sample companies' data including financial data, we visited companies and performed in-depth interviews with 45 cessation/failure CMDP cases out of 212 in the period 2000-2005. Interviews were conducted with each company's R\&D director or CEO, and a technology development evaluation was performed by our research members who were veteran. The researchers made a note during the interviews and the later, these notes were coded with the process suggested by Julie et al. (2007). We extracted key information using four key steps: immersion in the data, coding, creating categories, and the identification of themes (Julie et al., 2007). In coding process we examined and organised the information contained in each interview and the whole dataset. All the codes were sorted to different categories and we indentified the three themes (Management, Technology and Others). 


\section{Analysis and Findings}

\subsection{Case Analysis}

\subsubsection{Background}

In order to grow with a balanced manufacturing economy, the CMDP supports source technology development of core parts and materials that are essential to raise competitiveness with potential for a wider impact on industry. The Ministry of Knowledge Economy(MKE) have offered this program since 2001 and through it, 412 companies have been selected whereby 212 companies finished their project development during $2001-2005$. Each year the MKE announces a technology road map which needs to be developed to create national wealth; many companies follow it. This program uses a 'selection' and 'concentration' policy, so the competition rate for the program is very high. However, government funding is quite high and averages about 2.5 billion Korean Won (KRW) per project during 2000-2005.

In order to be selected, applicants need to pass two stages; firstly, the applicant should pass the technology evaluation stage, which is essential, and follows the same procedure as other Korean Government funding criteria. At the second stage, interestingly, this program requires applicants to receive investment funds from private investment organizations, whereby the amount of the investment fund should be over-and-above the government fund. The main reason why the government uses this method is that they want to leverage the evaluating ability of professional investment organizations to increase efficiency of the government funding program and to achieve their policy aims. Additionally, this method used so that companies can acquire funds for their business and gain additional business support from an investment organization.

When companies are selected they receive government funds for technology development use, and receive investment funds from investors for business operating use. After selection, the government and its agency audit these companies to monitor their technology and financial performances every year. After the audit, the government notifies the audited company of their results and advises them to continue or to cease the project, as well as whether they have successfully completed the project or failed.

As seen in Table 1, 412 companies were selected and funds of 10,084 million KRW were invested during $2000-$ 2005. 50 of those companies were ceased as they failed in their development.

Table 1. Materials and components development project status

(2005. 12 Rating, Unit: Companies)

\begin{tabular}{|c|c|c|c|c|c|c|c|}
\hline$\frac{0}{0}$ & 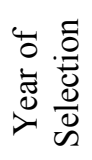 & 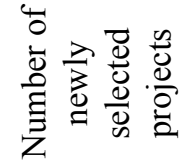 & 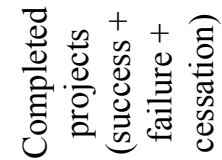 & 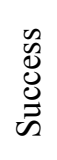 & $\underset{\Xi}{\stackrel{\Xi}{\Xi}}$ & 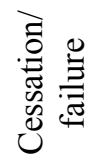 & 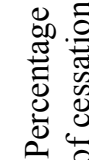 \\
\hline
\end{tabular}

\begin{tabular}{cccccccc}
\hline Sole Subjective & 2000 & 42 & 42 & 33 & 4 & 5 & $11.9 \%$ \\
Sole Subjective & 2001 & 68 & 67 & 56 & 2 & 9 & $13.4 \%$ \\
Sole Subjective & 2002 & 61 & 55 & 41 & 5 & 9 & $16.4 \%$ \\
Sole Subjective & 2003 & 52 & 19 & 12 & 1 & 6 & $31.6 \%$ \\
Sole Subjective & 2004 & 56 & 4 & 1 & & 3 & $75.0 \%$ \\
Sole Subjective & 2005 & 58 & 1 & & & 1 & $100.0 \%$ \\
Sole Subjective & Total & 318 & 188 & 143 & 12 & 33 & $17.6 \%$ \\
Co-sponsorship & 2000 & 3 & 3 & 3 & & & $0 \%$ \\
Co-sponsorship & 2001 & 7 & 7 & 6 & & 1 & $14.3 \%$ \\
Co-sponsorship & 2002 & 17 & 12 & 9 & & 3 & $25.0 \%$ \\
Co-sponsorship & 2003 & 25 & 2 & 1 & & 1 & $50.0 \%$ \\
Co-sponsorship & 2004 & 23 & & & & & - \\
Co-sponsorship & 2005 & 19 & & & & 5 & - \\
Co-sponsorship & Total & 94 & 45 & 19 & & 5 & $11.1 \%$ \\
Total & 2000 & 45 & 45 & 36 & 4 & 10 & $13.5 \%$ \\
Total & 2001 & 75 & 74 & 62 & 2 & 10 \\
\hline
\end{tabular}

* Sole subjective: Technology development project performed by one company.

** Co-sponsorship: Technology development project performed by one supervision company and other service company. 


\subsubsection{Details of Cessation/Failure Projects}

\subsubsection{Cessation / Failure Project Status by Industry}

As shown in Table 2 below, selected companies were chosen from 7 industries which included metals, machinery, textiles, automotive, electrical, electronics, and chemical industries. A high proportion are seen as electronic $(14.9 \%)$, textiles $(13.6 \%)$, automobiles $(13.6 \%)$, machinery $(11.5 \%)$, chemicals $(10.1 \%)$, metals $(9.1 \%)$, and electricity (3.4\%). Although the electronic industry project's cessation, in respect of failure, numbered the highest (26), it is mainly due to the relatively high selection of companies from within that industry. All industries seem to show a similar rate of cessation/failure distribution when considering their rates of selection.

Table 2. Cessation/Failure project status by 7 industries

(Unit: number, \%)

Average

Project status by 7 areas Metal Machinery Textile Automobile ElectricityElectronChemistry /

\begin{tabular}{cccccccccc}
\hline $\begin{array}{c}\text { Number of cessation/failure projects } \\
\text { Cessation/failure project rate }\end{array}$ & 4 & 6 & 3 & 3 & 1 & 26 & 7 & 50 \\
$\quad \begin{array}{c}\text { compared } \\
\text { to selection }\end{array}$ & $9.1 \%$ & $11.5 \%$ & $13.6 \%$ & $13.6 \%$ & $3.4 \%$ & $14.9 \%$ & $10.1 \%$ & $12.1 \%$ \\
$\begin{array}{c}\text { Number of successful projects } \\
\text { Successful project rate compared to }\end{array}$ & 16 & 13 & 5 & 3 & 22 & 79 & 24 & 162 \\
$\quad$ selection & $36.4 \%$ & $25.0 \%$ & $22.7 \%$ & $13.6 \%$ & $75.9 \%$ & $45.4 \%$ & $34.8 \%$ & $39.3 \%$ \\
$2000-2005$ Selected projects & 44 & 52 & 22 & 22 & 29 & 174 & 69 & 412 \\
\hline
\end{tabular}

* Number of selected projects $=($ number of success projects $)+($ Number of cessation and failure projects $)+$ (Number of ongoing projects)

\subsubsection{Cessation / Failed Project Status by Number Of Employees}

As shown in Table 3 below, companies that had less than 40 employees accounted for $68 \%$ of the total cessation/failure projects (50).

Table 3. Cessation/Failure project status by number of employees

(unit: number,\%)

\begin{tabular}{cccccccc}
\hline Number of employees (person) & $\begin{array}{c}\text { Less than } \\
\text { Number of cessation/failure projects }\end{array}$ & 20 & $20-40$ & $40-60$ & $60-80$ & $80-100$ & 100 \\
Proportion & $44 \%$ & $24 \%$ & 12 & 5 & 4 & 2 & 5 \\
Number of successful projects & 53 & 42 & 22 & 13 & $7 \%$ & $10 \%$ \\
Proportion & $32.7 \%$ & $25.9 \%$ & $13.6 \%$ & $8.0 \%$ & $4.3 \%$ & $15.4 \%$ \\
\hline
\end{tabular}

\subsubsection{Cessation / Failure Project Status by Establishment Year}

As shown in Table 4 below, companies that had been established for less than 3 years accounted for $60 \%$ among the total cessation/failure project cases (50). 
Table 4. Status by establishment year

\begin{tabular}{|c|c|c|c|c|c|c|c|c|}
\hline Year of selection & $\begin{array}{c}\text { Less than } 1 \\
\text { year }\end{array}$ & $\begin{array}{c}\text { More than } \\
1 \text { - less } \\
\text { than } 2\end{array}$ & $\begin{array}{l}\text { More than } \\
2 \text { - less than } 3 \\
3\end{array}$ & $\begin{array}{l}\text { More than } \\
3 \text { - less than } \\
4\end{array}$ & $\begin{array}{l}\text { More than } 1 \\
4 \text { - less than } 5 \\
5\end{array}$ & $\begin{array}{l}\text { More than } \\
15 \text { - less than } \\
10\end{array}$ & $\begin{array}{c}\text { More than } \\
10\end{array}$ & Total \\
\hline 2000 & 12 & 7 & 4 & 1 & 3 & 8 & 10 & 45 \\
\hline 2001 & 13 & 28 & 6 & 5 & 4 & 6 & 13 & 75 \\
\hline 2002 & 2 & 11 & 21 & 7 & 5 & 12 & 20 & 78 \\
\hline 2003 & & 8 & 11 & 12 & 6 & 12 & 28 & 77 \\
\hline 2004 & 2 & 4 & 6 & 8 & 12 & 20 & 27 & 79 \\
\hline 2005 & & 4 & 3 & & 6 & 18 & 27 & 58 \\
\hline Total & 29 & 62 & 51 & 33 & 36 & 76 & 125 & 412 \\
\hline $\begin{array}{c}\text { Number of } \\
\text { cessation/failure } \\
\text { projects }\end{array}$ & 7 & 11 & 12 & 5 & 3 & 7 & 5 & 50 \\
\hline $\begin{array}{l}\text { Cessation/failure } \\
\text { project rate } \\
\text { compare to } \\
\text { selection }\end{array}$ & $24.1 \%$ & $17.7 \%$ & $23.5 \%$ & $15.2 \%$ & $8.3 \%$ & $9.2 \%$ & $4.0 \%$ & $12.1 \%$ \\
\hline $\begin{array}{c}\text { Number of } \\
\text { successful projects }\end{array}$ & 20 & 45 & 30 & 15 & 13 & 20 & 19 & 162 \\
\hline $\begin{array}{l}\text { Successful project } \\
\text { rate compare to } \\
\text { selection }\end{array}$ & $69.0 \%$ & $72.6 \%$ & $58.8 \%$ & $45.5 \%$ & $36.1 \%$ & $26.3 \%$ & $15.2 \%$ & $39.3 \%$ \\
\hline
\end{tabular}

* Number of selected project $=($ number of successful projects $)+($ Number of cessation/failure projects $)+$

(Number of ongoing projects)

\subsection{Key Factors of Cessation / Failure Projects}

We analyzed the data of the 45 cessation/failure companies except for 5 uncollectable project data. As seen in Table 5 below, cessation/failure factors of these companies comprised of technology, management and others. These factors acted together to impact on technology development cessation/failure rather than on their own. Also, there was a close relationship between these factors as research indicated that they influence each other. In addition, we found that the constraint factors affected each company as a different impact and if the company overcame these constraint factors properly, they successfully completed their technology development. If not, they had to cease the project or fail with their development. However, some companies had one clear constraint factor (e.g. not sufficiently developed technology, bankruptcy, or termination). 
Table 5. Cessation/Failure factors of smes in Korea (45 projects)

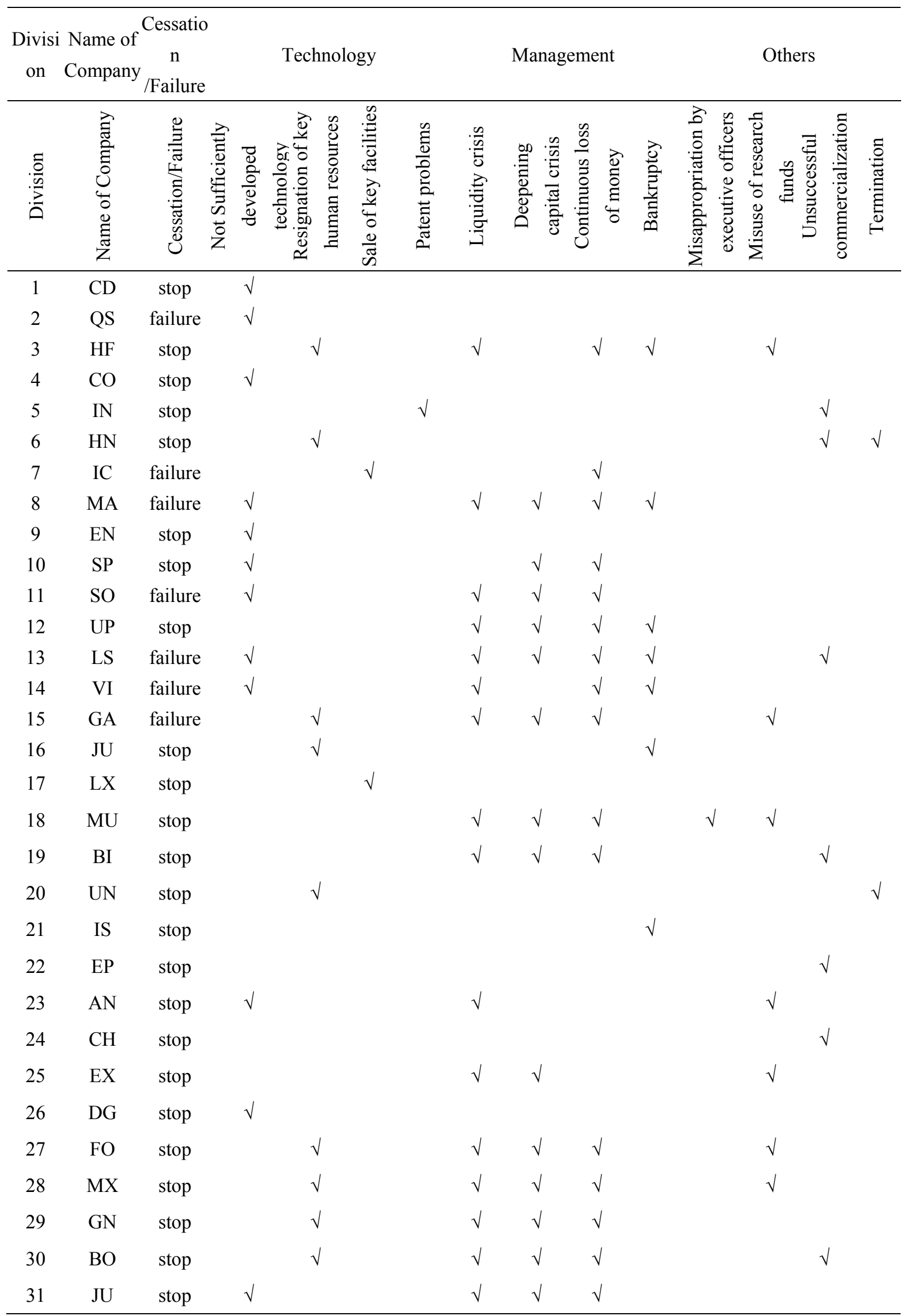




\begin{tabular}{|c|c|c|c|c|c|c|c|c|c|c|c|c|c|c|c|c|c|}
\hline $\begin{array}{c}\text { Divisi } \\
\text { on }\end{array}$ & $\begin{array}{l}\text { Name of } \\
\text { Company }\end{array}$ & $\begin{array}{l}\text { Cessati } \\
\text { n } \\
\text { /Failure }\end{array}$ & & & Tec & hnol & ogy & & & Manas & semen & & & \multicolumn{4}{|c|}{ Others } \\
\hline 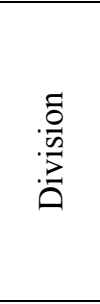 & 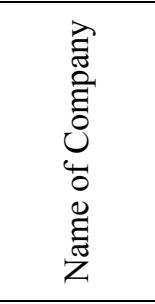 & 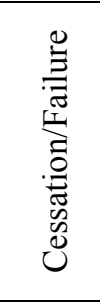 & 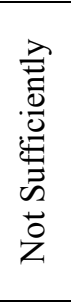 & $\begin{array}{l}\text { D. } \\
\frac{0}{0} \\
\frac{0}{0} \\
\frac{\pi}{0}\end{array}$ & 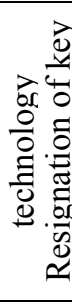 & 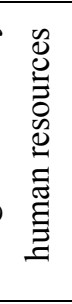 & 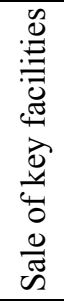 & 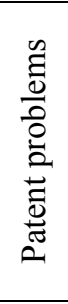 & 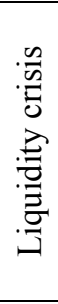 & 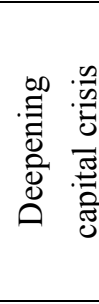 & $\begin{array}{l}\text { v } \\
0 \\
0 \\
0 \\
0 \\
0 \\
. \\
0 \\
0 \\
0 \\
0\end{array}$ & 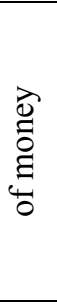 & 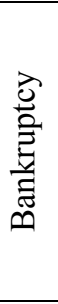 & 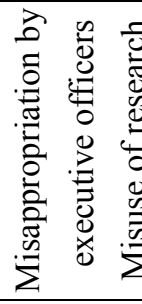 & 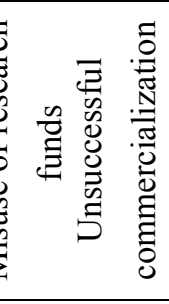 & 兽 & \\
\hline 32 & $\mathrm{OP}$ & stop & & & & & $\sqrt{ }$ & & $\sqrt{ }$ & $\sqrt{ }$ & $\sqrt{ }$ & & $\sqrt{ }$ & & $\sqrt{ }$ & & \\
\hline 33 & NU & stop & & & & & & & $\sqrt{ }$ & & & & & & $\sqrt{ }$ & & \\
\hline 34 & SY & stop & & & & $\sqrt{ }$ & & & $\sqrt{ }$ & $\sqrt{ }$ & $\sqrt{ }$ & & $\sqrt{ }$ & & & & \\
\hline 35 & WI & stop & & & & $\sqrt{ }$ & & & $\sqrt{ }$ & $\sqrt{ }$ & & & $\sqrt{ }$ & & & & \\
\hline 36 & DA & stop & & $\sqrt{ }$ & & & & & & $\sqrt{ }$ & $\sqrt{ }$ & & & & & & \\
\hline 37 & TW & failure & & $\sqrt{ }$ & & $\sqrt{ }$ & & & & & & & & & & & \\
\hline 38 & PX & stop & & $\sqrt{ }$ & & & & & $\sqrt{ }$ & $\sqrt{ }$ & $\sqrt{ }$ & & & & $\sqrt{ }$ & & \\
\hline 39 & HA & stop & & & & & & & $\sqrt{ }$ & $\sqrt{ }$ & & & $\sqrt{ }$ & $\sqrt{ }$ & & & \\
\hline 40 & NA & failure & & $\sqrt{ }$ & & $\sqrt{ }$ & $\sqrt{ }$ & & & & & & & & & & \\
\hline 41 & IO & stop & & $\sqrt{ }$ & & $\sqrt{ }$ & $\sqrt{ }$ & & & & & & & & $\sqrt{ }$ & & \\
\hline 42 & $\mathrm{SO}$ & stop & & $\sqrt{ }$ & & & & & $\sqrt{ }$ & $\sqrt{ }$ & $\sqrt{ }$ & & & & $\sqrt{ }$ & & \\
\hline 43 & PE & stop & & $\sqrt{ }$ & & $\sqrt{ }$ & & & $\sqrt{ }$ & $\sqrt{ }$ & & & & & & & \\
\hline 44 & SS & stop & & & & & & & & & & & & & & $\sqrt{ }$ & \\
\hline 45 & PO & stop & & $\sqrt{ }$ & & $\sqrt{ }$ & & & $\sqrt{ }$ & $\sqrt{ }$ & & & & & $\sqrt{ }$ & & \\
\hline
\end{tabular}

We analyzed each factor (technology, management, and others), and classified them in more detail. Firstly, technology factors included not sufficiently developed technology, resignation of key human resources, sale of key facilities, and patent problems. Research shows that technology factors occur when a project's R\&D performance fails. Projects experience trouble with continued development due to the resignation of key human resources, non arrival or absence of a main facility.

Management factors were classified as liquidity crisis, deepening capital crisis, continuous loss of money and bankruptcy. The liquidity crisis was measured by current ratio (current assets / current liabilities * 100), which shows the capacity of the business to meet short-term financial commitments as they become due. We considered $>50 \%$ as a crisis and for this research we used data from the previous year of the cessation/failure year. In order to identify a deepening capital crisis, we used the capital impairment ratio (net loss / equity * 100), and we considered $<30 \%$ as causing a serious problem. Similarly, we selected a continuous loss of money as the main factor because this also critically influenced the company's cash flow. Lastly, we added bankruptcy and closure as factors.

Finally, we classified other factors as misappropriation by executive officers, misuse of research funds, unsuccessful commercialization, and termination. Misappropriation by executive officers refers to an executive's moral hazard and embezzlement which creates a projects cessation/failure even though the company might have excellent technology. Misappropriation by executive officers is likely connected to bankruptcy due to a SMEs nature, especially, due to its heavy dependence on directors.

In the case of a company misusing research funds, some cases were investigated by KITIA in error and other cases were investigated intentionally because of the company's bad financial status. Unsuccessful commercialization happens when a market changes rapidly, and this makes their underdevelopment technology or product obsolete after then necessarily leading the SMEs to cease their development. Lastly, termination without any special 
difficulty in regard to technology and management was another factor.

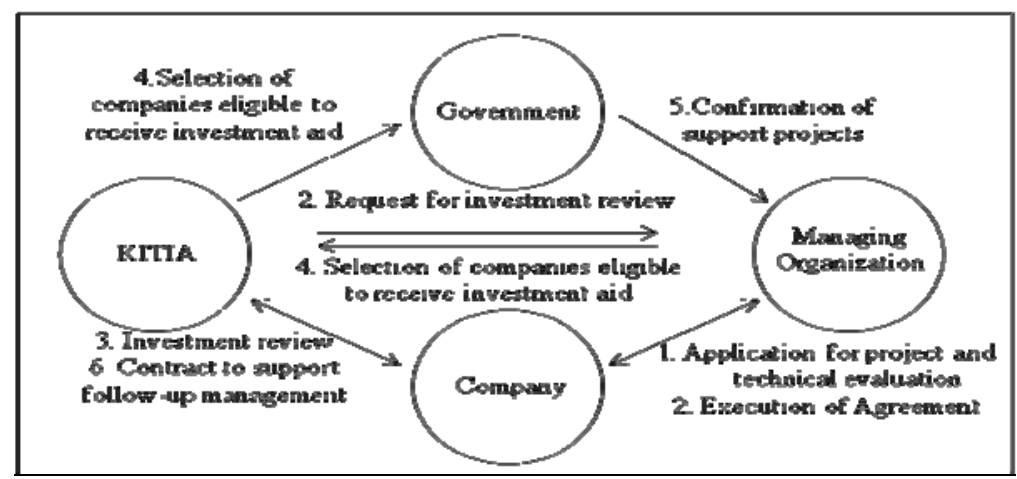

Figure 1. The parts and materials development project

As seen in Figure 1, we sorted the data of the 45 companies by factors that directly affected their cessation/failure. According to the result, 32 cases were affected by complex factors, 8 cases by pure technology factors, and 2 cases by pure management factors. From these results we find that because companies are similar in nature to a human organism, cessation/failure cases can generally be caused by complex interactions within them (refer to Figure 2).

As cessation/failure factors act together, we needed to further investigate each factor in depth. For this, we analyzed each project by cessation/failure factors and summarized our findings in Graph 3 . According to the results, management aspects showed the highest at 80 cases, technology aspects recorded 42 cases, and other aspects followed with 25 cases. The reason why management aspects ranked at the top is due to a lack of funds for $\mathrm{R} \& \mathrm{D}$, and this factor connected with a lack of human resources (technicians) and equipment, whereby they caused the cessation/failure of the project.

As seen in Figure 2, pure technology factor cases were 2. One reason was a company's failure to resolve technical problems, and the other reason, was the project's unclear commercialization strategy. Conversely, we found that the pure management factor related to insufficient funding to proceed with $R \& D$.

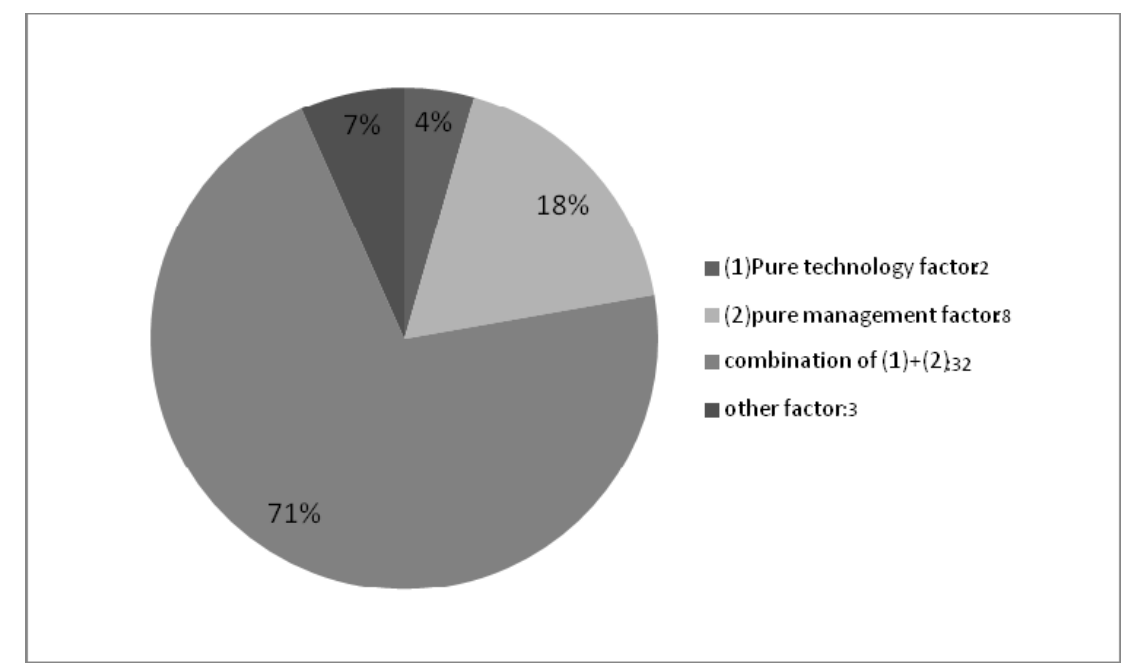

Figure 2. Causes of the cessation/failure

Liquidity crisis revealed the highest number of cases (25), deepening capital crisis marked 23 cases, technology problems 20 cases, resignation of key human resources 16 cases, misuse of research funds 13 cases, unsuccessful commercialization (trend changes) 7 cases, sale of major facilities 5 cases, termination 3 cases, misappropriation by executive officers 2 cases, and patent problems 1 case. 


\subsection{Main Factors of Cessation / Failure}

\subsubsection{Technology Development Factors}

\subsubsection{Not Sufficiently Developed Technology}

As seen in Figure 3, technology problem cases were the highest of the technology sector, in spite of the best efforts of the companies. Results indicate that most of the companies failed due to a lack of ability, and others failed because of the speed at which technological development changed. For example, the projection television market, which was predicted as high-growth, became obsolete within a few years. Similarly, the mobile component market demand changed rapidly from cellular phones to smart phones. A few companies failed because they could not overcome the expectation to produce world-class technology.

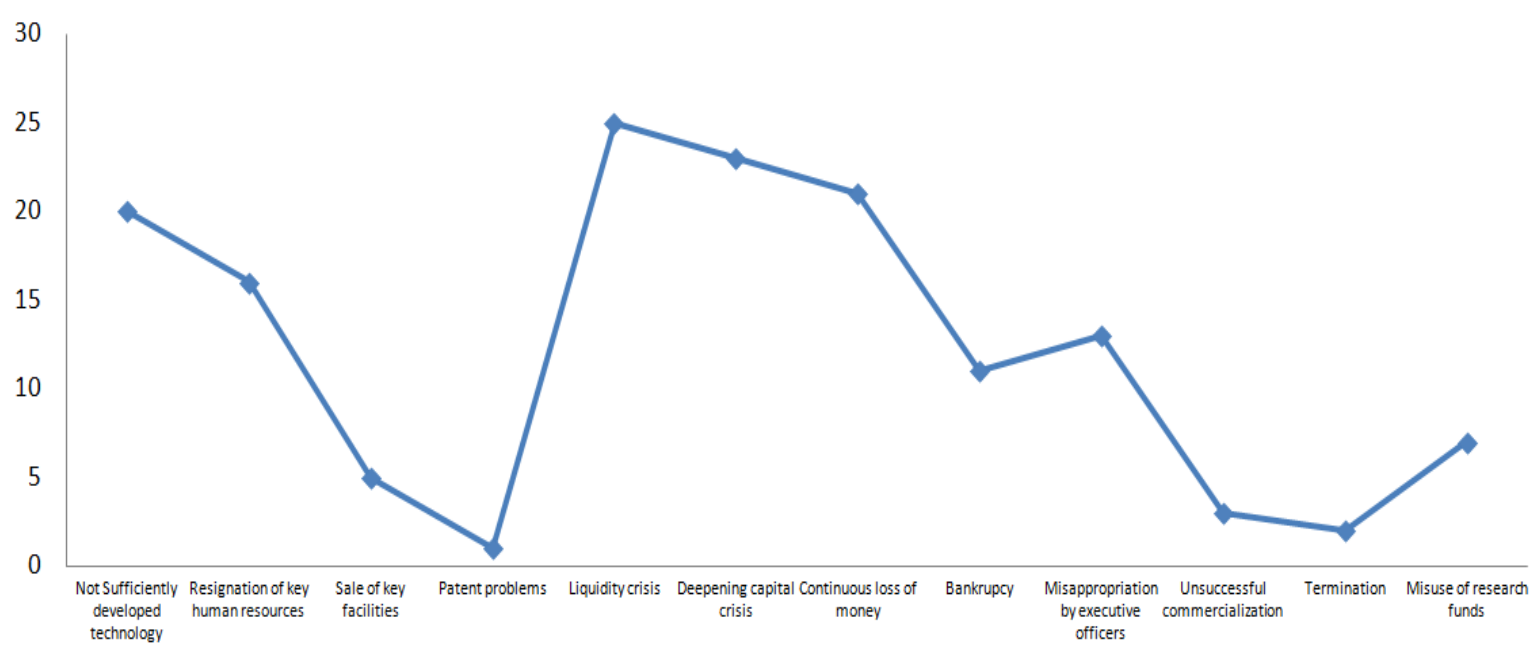

Figure 3. Main factors of cessation/failure

CDs project failed due to the company not having sufficiently developed their technology. The project's purpose was to develop the display nano particle electric discoloration element. While they faithfully performed development as scheduled, and successfully registered a patent for the polymer EL substance synthesis, their technology development result was not sufficient; it did not match their planned aim for luminance 500-1,000 $\mathrm{cd} / \mathrm{m}^{2}$ and lifespan 2,000-10,000 hr. Eventually, the project failed. In the case of EN, they planned to develop a small adapter and integrated circuit(IC) for the inside use of laptops. However, at the mid technology performance evaluation, the result showed the following problems; lack of differentiation with existing products, low reliability of the prototype, and insufficient design for building it into laptops. Therefore, the project failed.

\subsubsection{Resignation of Key Human Resources}

As seen in Figure 3, the resignation of key human resources was the second highest case total of the cessation/failure. Normally, resignation of key human resources causes technology development interference so managing people with care is one of the most important keys to success. The chief technology officer (CTO) is regarded as being of similar rank to a director, so a company's project performance ability is too centralized, and other options do not exist. If when the CTO resigns, a project is usually critically damaged. To prevent this problem, the investment organization includes prohibition terms like 'no termination of CTO' as a safety device within the contract.

UNs project pertained to the development of a screen roller and fine mesh for preventing electromagnetic charges using the pole technique. Due to the resignation of five key human development technology staff working on the pole technique at a time, the attainment of the development aim became unclear, therefore causing the UN to liquidate its pole development department and terminate the project.

\subsubsection{Sale of Key Facilities}

As seen in Figure 3, sale of facilities included 8 cases of the total number of cessation/failure projects investigated. These cases were categorized by two reasons. Firstly, companies were unable to develop technology because of the sale of their main facilities, and secondly, companies purchased different facilities from those they submitted in their research proposal application to the government. Mostly, companies sold their facilities or misused the 
equipment funds they received because of financial difficulties. However, there were a few companies that demanded research funds to purchase facilities, in spite of the fact that they already had a facility.

LX performed development of the back light led luminescence package for the side of the liquid crystal display (LCD) panel. Midway through the development they asked to change facilities and equipment, however during a special evaluation their demand was denied. According to the special evaluation result, LX performed their development by outsourcing and the government judged their request as being unreasonable and finally they ordered that the project cease.

\subsubsection{Patent Problems}

As seen in Figure 3, patent problems are caused by other companies pre-empting developing projects whereby they lost their usefulness. If from within a SMEs small number of patents, which are specialized for their business, one becomes a problem, it may cause serious concerns and affect the SME unfavourably. This is the reason why it is emphasized that SMEs should systematically protect their developing patents.

In developing integrated complex chips, $\mathrm{RC}$ and $\mathrm{RN}$ needed mobile devices and although they successfully completed their first year of development as planned, their projects had to cease because of patent problems. The main reason for their patent problems was that the market demand changed to one-step advanced technology which called for the use of a multi-chip technology. However, it was noted that the MCM patent was already registered to a United States of America company (AVX). Further, other source patents were also already registered by other companies too. As a result IN's project became obsolete and the project was stopped.

\subsubsection{Management Factors}

\subsubsection{Liquidity Crisis}

As seen in Figure 3, a liquidity crisis accounts for the highest number at 25 with a deepening capital crisis following. The main reasons are due to overspending on development, or due to a business sales slump while performing that development (i.e. if there is no sales while performing development, a liquidity crisis can occur rather easily), in addition to an occurrence of contingency debt. Important to note, some of these companies became bankrupt, therefore they did not only fail in terms of their development project.

ANs project was to develop a thin-film, bulk-wave acoustic resonator (FBAR) duplexer for the IMT-2000 band by a low temperature co-fired ceramic (LTCC) board. AN, at the time of their technology development application, had poor cash flow due to financial deterioration and increased debt, therefore they had overdue accounts, mature debt, and interest from other debts. It was for this reason that AN misused their government funds to repay their debt and interest, as well as staff salaries. Their project finally failed. In addition, AN did not pay their joint venture partners, so they did not produce any products.

\subsubsection{Deepening Capital Crisis}

As seen in Figure 3, a deepening capital crisis showed the second highest number of cases (23), this was mainly caused by a continuous loss of money. In some cases, companies tried to find a cash cow through new technology development, however, due to not having enough money the project ended eventually without success. In the worst scenario, a deepening capital crisis was sometimes connected to a misuse of research funds.

DAs project was to develop a wound radio frequency (RF) chip inductor 1005 (0402) type. As DAs previous sales were as few as 70 million KRW, they concentrated their competency on their development project. However, continual loss without sales over two years brought on a deepening capital crisis due to lack of funds, and as a result, the project was stopped.

\subsubsection{Continuous Loss of Money}

As seen in Figure 3, continuous loss of money was the primary reason behind 21 cases. It was found that the loss was linked to rapid liquidity degradation and therefore caused most companies within this situation to stop their project development. The root cause of a continuous loss of money comes from a loss of core business and this mostly brings about a liquidity crisis which then leads to bankruptcy.

\subsubsection{Bankruptcy}

As seen in Figure 3, bankruptcy totalled 11 cases, and research indicated that this mostly comes from no or low sales performance and a deterioration of the company's financial status. There seems to be a close relationship between bankruptcy, liquidity crisis, deepening capital crisis, continuous loss of money, moral hazard, embezzlement, and fleeing. 
IS had planned to develop aluminium parts for suspension through their own casting method. One year after starting development, the company declared bankruptcy, and the project stopped. Looking at ISs financial statements from 1 year before the bankruptcy (2003), their current liability was high at 326 billion KRW out of a total liability of 571 billion KRW, and a further $90 \%$ of the current liability ( 292 billion KRW) was their short-term borrowings with less than 3 months maturity.

\subsubsection{Other Factors}

\subsubsection{Misuse of Research Funds}

As seen in Figure 3, a misuse of research funds records the highest mark of all the other major causes at 13 cases. Most of these cases were because the company experienced financial difficulty so they misused research funds to pay their debt or employee salaries.

NU participated in a program to develop graded-index plastic optical fiber(GI-POF) which would have had a 2 Gbps-100m bandwidth between $780-850 \mathrm{~mm}$. This company withdrew government funds without approval, and used them for other purposes, such as repaying borrowings.

\subsubsection{Unsuccessful Commercialization (Trend Changes)}

As seen in Figure 3, unsuccessful commercialization totalled 7 cases. Most of these cases got this way because of competitors from either domestic and overseas who preoccupied the market. However, some were because the market trend they were following changed before the development was complete. In the case of the bio industry, the government approval process is a strong barrier which can be viewed as a constraint that affected companies moving into the industry.

$\mathrm{CH}$ participated in a program to develop a camera system on-chip Application Specific Integrated Circuit (ASIC) using a charge coupled device (CCD) digital signal processor. Even though the development performance was excellent, competitiveness and commercialization of the final developed product was expected to be unsuccessful and the project was stopped. Although the trend of the network camera at that time was moving picture experts group 4(MPEG4) as a standard rather than moving-joint photographic experts group (M-JPEG), this project goal aimed for just upgrading exist technology and couldn't catch up with the trend of the market.

\subsubsection{Termination}

In Figure 3, termination cases were 3. Management deterioration, resignation of key research human resources, and a changed business scope with a foreign joint venture company were the underlying reasons for the failure of each case.

SS participated in a program to develop an annular condenser for the home air conditioning system. VV, an interim investor of SS requested that the development project be abandoned for no reason. SS accepted their request and refunded the government their funds and declared the project terminated.

\subsubsection{Misappropriation by Executive Officers}

In Figure 3, the misappropriation by executive officer totalled 2 cases. Misappropriation by executive officers occurred due to management deterioration, and because of this, both companies discontinued development. Also, research shows that a key determinant of management deterioration is the executive officers moral hazard. For this reason, at the time of government funding selection, the selectors should observantly consider the company's basic financial strength, in other words, whether the applicant can successfully complete the project or not.

MU was going to develop lead-free solder balls for a surface mount. This project stopped as every researcher resigned because of the misappropriation of funds by the executive officer who embezzled the public funds and fled overseas. According to the post project examination, poor internal control systems within the company were the cause. Segregation of the duty of funds was ignored as all funds were controlled by the executive. The OP company was to develop 3-4 generation image amplification tubes. Before the project stopped, OP suffered a serious shortage of cash flow and this caused a liquidity crisis. This was due to the executive officer's moral hazard (misuse of company funds etc), which was found to be the case through an investigation and the project was stopped.

\section{Conclusion and Implications}

In this paper, we investigated cessation/failure factors of government funded technology development projects which is an important part of the technology innovation system in Korea. As a result, we provided a theoretical basis to maximize the effectiveness of the national development policy to find a way forward for technology innovation improvement for companies that want to grow as an enterprise through the use of developed 
technology by commercialization. While most of the existing research focuses on innovation capacity, market, technology innovation capacity, commercialization, and venture companies failure factors, as well as verification and identification of causality relationships by survey, there are few research papers that are based on case verification. This research has significant meaning and provides a basis for future research by analyzing parts and material technology development case studies relating to the technology factors, management factors, and other factors.

Generally, when reviewing each of the cessation/failure companies, we noted that the companies were small. The number of companies that had less than 40 employees consisted of 34 (68\%), the number of companies that were established less than 3 years prior to the commencement of the program were $30(60 \%)$, and the number of companies that had sales of less than 10 billion KRW per year were $25(50 \%)$. Such a small firm size eventually leads to low resistance to overcome the technical/managerial problems that occur during the development period. This is an important reason that perpetuates a vicious circle of: technology problems $\rightarrow$ management problems $\rightarrow$ other problems $\rightarrow$ technology development cessation/failure. In order to improve SMEs technology innovation ability, a pre-emptive response is needed by identifying technology/management problems which could occur during the technology development stage in advance. Our summarized analysis results are as follows.

Firstly, cession/failure through technical factors are classified as not sufficiently developed technology, resignation of key human resources, sale of key facilities, patent problems, which eventually result in a lack of technology competency for the company. For example, a project fails to achieve their development goal, the project development fails to catch up with market trends, and then the company's development fails because the international standard has changed. Therefore, in order to prevent technology development cessation/failure due to technical factors, well organized research teams who have technical innovation competency should develop market oriented technologies through market research.

Secondly, cession/failure by management factors are classified as liquidity crisis, deepening capital crisis, continuous loss of money, and bankruptcy. All these factors brought about a lack of funds which companies needed essentially for the purchasing of facilities or for their operations. In the absence of a company's cash cow, and if the company is too dependent on the sales forecast from the developing technology, these SMEs will experience financial troubles at the time of commercialization and the likelihood of their success will be diminished. Also, in order to achieve business success and economies of scale, SMEs should supply their goods to large enterprises. However, in most instances, their reliability tests take years. Realistically, there are few SMEs that have enough funds to use for R\&D activities, and many SMEs have no sales at all. This poor financial situation always causes management problems. Fortunately, parts and material technology development companies that participate in the CMDP have steady government funding and investment funding from investment organizations. Consequently, they can succeed with their projects and with the commercialization of their developed products.

Third, cession/failure by other factors is classified as misappropriation by executive officers, misuse of research funds, unsuccessful commercialization, and termination. Due to the nature of small businesses being highly dependent on executive officers and executives for leadership of the development program, if these executive officers are immoral, it affects their companies critically. It is also very hard to determine if there is a negative intention, as well as no way to stop the consequences of that negative intention. If SMEs set up secure internal control systems, these problems could be prevented. However, in spite of SMEs knowing that these controls will be beneficial to them, they often avoid them because of the high costs and great effort required. Also, there were many misappropriation cases conducted by the collusion of managers and other employees. These problems should be solved eventually by reinforcing regular internal audits and outside monitoring.

Fourth, we found that most of the cessation/failure cases were due to a combination of the three factors (technology, management, and other factors). Companies are often likened to an organism, and thus, technology, product and market are considered to be that organism. Nonetheless, the market is considered to be the most important aspect of the three. That means the development of commercial technology is the key factor, and this result is verified by Laforet (2007) from his study regarding the effects of the market and firm size on innovation. Also, Yam et al. (2010) published a similar study on technology innovation which found.

Finally, this study examined cessation/failure cases within the parts and materials industry which is a core part of the industry value chain as a middle position between upstream and downstream. In particular, the nature of the parts and material industry means it is affected by upper and lower industry in respect to technology development and commercialization. Consequently, we need to increase the range of research to include upper and lower industry. This study's limitation is that of generalization, in that, the structural characteristics of each industry 
have not been considered. Therefore, to acquire significance, we need to undertake an additional study to increase the sectors and research scope.

\section{References}

Burgelman, R., \& Maidique, S. (1995). Strategic management of technology and innovation. Chicago: Irwin.

Brockman, B., \& Morgan, R. (2003). The role of existing knowledge in new product innovativeness and performance. Decision Science, 34, 385-419. http://dx.doi.org/10.1111/1540-5915.02326

Choi, G. (2010). The growth strategies of technology-based materials and components firms. SME Research, 32 (4), 27-55. Retrieved from http://www.riss.kr/link?id=A82492048

Chan, J., Martin, D., \& Kensinger, J. (1990). Corporate research and development expenditures and share value. Journal of Financial Economics, 26(2), 255-276. http://dx.doi.org/10.1016/0304-405X(90)90005-K

Eisenhardt, K. (1989). Building theories from case study research. Academy of Management Review, 59, 547-570 Retrieved from http://www.jstor.org/stable/258557

Eisenhardt, K., \& Grabner, M. (2007). Theory building from cases: opportunities and challenges. Academy of Management Journal, 50, 25-32. http://dx.doi.org/10.5465/AMJ.2007.24160888

Forsman, H. (2011). Innovation capacity and innovation development in small enterprises: A comparison between the manufacturing and service sectors. Research Policy, 40, 739-70. http://dx.doi.org/10.1016/j.respol.2011.02.003

Jang, S. (2007). Risk management of high-tech ventures across the growth stages: Age-dependent risk, resource-based buffers, and survival. Venture Management Research, 10(1), 33-54. Retrieved from $\mathrm{http}: / /$ www.riss.kr/link?id=A75647244

Julie, G. (2007). Generating best evidence from qualitative research: the role of data analysis. Australian and New Zealand Journal Of Public Health, 31(6), 545-550. http://dx.doi.org/10.1111/j.1753-6405.2007.00141.x

Kirner, E., Kinkel, S., \& Jaeger, A. (2009). Innovation paths and the innovation performance of low-technologyirms - an empirical analysis of German industry. Research Policy, 38(3), 447-458. http://dx.doi.org.libraryproxy.griffith.edu.au/10.1016/j.respol.2008.10.011

Kim, K. (1991). A study on the promotional measures for the commercialization of the research results. Korea Scieence and Engineering Foundation, Retrieved from http://www.riss.kr/link?id=M4630676

Kim, J. (2007). A study on the promoting methods for innovative SMEs based on technology innovation types.

policy research 2007-06. Science and Technology Policy Institute. Retrieved from http://www.riss.kr/link?id=M4630676

Kyung, J., \& Lee, B.(2010). An approach to differentiate business support policies for reinforcement of small-medium enterprise competency by growth stages. SME Research, 32(1), 57-79. Retrieved from http://www.kasbs.or.kr/payBBS/bbs.asp?bbs=learned\&act=read\&no=1656

Lee, D., \& Jeong, R.(2010). A study on effect of technological innovation capability and technology commercialization capability on business performance in SMEs of Korea, SME Research, 32(1). 65-87. Retrieved from http://www.riss.kr/link?id=T11634549

Lee, J., \& Lee, S. (2009). Reasons of failure according to stages of new venture growth. SME Research, 31(3), 1-17. Retrieved from http://www.riss.kr/link?id=A76553689

Lee, C., Lee, K., \& Pennings, J. (2001). Internal capabilities, external network and performance: a study on technology-based ventures. Strategic Management Journal, 22(6/7), 615-640. http://dx.doi.org/10.1002/smj.181

Laforet, S. (2007). Size, strategic, and market orientation affects on innovation. Journal of Business Research, 61, 753-764. http://dx.doi.org/10.1016/j.jbusres.2007.08.002

Lussier, R., \& Halabi, C. (2010). A three-country comparison of the business success versus failure prediction $\begin{array}{lllll}\text { model. Journal of Small Business } & \text { Management, 48(3), } 377 .\end{array}$ http://dx.doi.org/10.1111/j.1540-627X.2010.00298.x

Miles, M. B., \& Huberman, A. M. (1994). An expended sourcebook. Qualitative data analysis, $2^{\text {nd }}$ ed., Sage publications, Thousand Oaks, CA. 
Park, J. (2008). A Study on innovation system of value chain. Seoul national university, Korea.

Souitaris, V. (2002). Technological trajectories as moderators of firm-level determinants of innovation, Research Policy, 31(6), 877-898. http://dx.doi.org.libraryproxy.griffith.edu.au/10.1016/S0048-7333(01)00154-8

Stake, R. (1995). The art of case study research, London: Sage.

Szeto, E. (2000). Innovation capacity: working towards a mechanism for improving innovation within an inter-organizational network. The TQM Manazine, 12(2), 149-158. http://dx.doi.org/ $10.1108 / 09544780010318415$

Teece, D. (1992). Competition, cooperation and innovation: Organizational arrangements for regimes of rapid technological progress. Journal of Economic Behavior and Organization, 18(1), 1-25. http://dx.doi.org/10.1016/0167-2681(92)90050-L

Teece, D. (2007). Explicating dynamic capabilities: the nature and microfoundations of (sustainable) enterprise performance. Strategic Management Journal, 28(13), 1319-1350. http://dx.doi.org/ 10.1002/smj.640

Yam, M., Guan, J., Pun, K., \& Tang, E. (2004). An audit of technological innovation capabilities in Chinese firms: some empirical findings in Beijing, China. Research Policy, 31(3), 543-567. http://dx.doi.org/10.1016/j.respol.2004.05.004

Yin, R. (2003). Case Study: Design and Methods. London: Sage. 